\title{
Jarak Optimum Panci Terhadap Selubung Pada Efisiensi Sistem Pemanasan Air
}

\author{
Agung Sugeng Widodo \\ Jurusan Mesin Universitas Brawijaya \\ JI. MT. Haryono 169, Malang, 65145 \\ Telp. : (0341) 587710. Fax : (0341) 551430 \\ E-mail : agung_sw@ub.ac.id
}

\begin{abstract}
Energy conservation from fossil fuel is urging to be implemented recently, including conservation in a conventional gas stove (CGS). Considering the mechanism of a CGS, there are many prospects to enhance its performance. In this study, efficiency of a CGS has been investigated by varying the gap between pan and stove cover. Many parameters were measured as energy from fuel, cover temperature and water temperature to develop efficiency equation of heating system. Ceramic cover was used to prevent heat release from flame. Gaps between pan and stove cover were varied in $1 \mathrm{~mm}$ to $7 \mathrm{~mm}$ with increment of 1 $\mathrm{mm}$. The results showed that in certain fuel rate of $45 \mathrm{l} / \mathrm{h}$, the gap of $4 \mathrm{~mm}$ indicated the highest efficiency of $46.4 \%$ due to the optimum condition was achieved simultaneous in convection and radiation heat transfer processes of the hontinn nistam
\end{abstract}

\section{PENDAHULUAN}

Sebuah data dari kementerian ESDM menyatakan bahwa biaya yang dikeluarkan untuk bahan bakar gas lebih murah karena hanya $60 \%$ dari BBM (www.esdm.go.id). Data subsidi minyak tanah pemerintah Indonesia dari tahun 2006 - 2008 adalah sebesar Rp. 105 trilyun yang dirasa terlalu membebani APBN, sehingga pada tahun 2006 mulailah dicanangkan program konversi minyak tanah ke LPG dan dimulai pelaksanaannya pada tahun 2007 (www.iisd.org). Berlanjut pada tahun 2007 - 2012 telah terjadi penghematan sebesar 70 trilyun (www.esdm.go.id). Konversi minyak tanah ke LPG menjadikan penggunaakan bahan bakar untuk kebutuhan rumah tangga juga meningkat. Akan tetapi, jika melihat mekanisme proses pembakaran pada kompor gas konvensional, maka masih terdapat kesempatan luas untuk melakukan penelitian mengenai penghematan bahan bakar gas tersebut.

Gohil, 2011 melakukan penelitian pada kompor gas konvensional secara umum. Hasilnya menunjukkan bahwa efisiensi sebesar $66 \%$. Gohil juga menyatakan bahwa efisiensi kompor gas konvensional tersebut data ditingkatkan lagi dengan penambahan peralatan berupa selubung dan mengoptimasi proses pembakaran pada kompor tersebut.

Peningkatan efisiensi sebesar 2,8 \% juga di dapatkan oleh Syarial, 2012, ketika mengaplikasikan sebuah reflektor (selubung) berbentuk primamida terbalik pada kompor gas berbahan bakar biogas dibandingkan tanpa reflektor.

Khan, 2013 juga malakukan penelitian mengenai kompor gas konventional. Khan melakukan perubahan material burner serta desain burner head. Dari perubahan tersebut didapatkan peningkatan efisiensi sebesar $10 \%$ pada perubahan material burner dari cast iron head burner menjadi brass hear burner. Terjadi pula peningkatan efisiensi sebesar $10 \%$ apabila bentuk head burner diubah dari flat burner.

Sebuah alat pengumpul diaplikasikan pada sebuah kompor gas konvensional. Tujuan dari alat pengumpul panas tersebut adalah untuk mendapatkan panas terbuang sebagai proses perpindahan panas konveksi dan radiasi untuk diarahkan ke sekeliling panci. Hasil menerapan alat pengumpul panas tersebut adalah peningkatan efisiensi sebesar $10 \%$ dibandingkan dengan tanpa alat pengumpul panas (Wardani, 2007).

Sebuah penelitian oleh Prima (2014) mengenai pengaruh jenis material selubung pada kompor gas konventional. Penelitian oleh Prima bertujuan untuk menerapkan sebuah selubung pada kompor gas konvensional, akan tetapi model aplikasi tersebut dibuat sedemikian rupa sehingga lebih praktis jika dibandingkan dengan model selubung oleh Wardani (2007). Hasil yang didapat menunjukkan bahwa selubung dengan material keramik menghasilkan peningkatan efisiensi sebesar $2,26 \%$ dari efisiensi sebelumnya tanpa menggunakan selubung. 
Sebuah indikasi terlihat pada penelitian oleh Prima (2014), yaitu ketika jarak panci dengan selubung sangat rapat, efisiensi kompor gas konvensional justru menurun drastis. Oleh karena itu, diperlukan sebuah penelitian mengenai jarak selubung terhadap panci untuk mendapatkan sebuah efisiensi yang maksimal dari sebuah kompor gas konvensional.

\section{Efisiensi Termal}

Kinerja sebuah kompor gas pada sistem pemanasan air dapat diukur dengan menggunakan istilah efisiensi karena kompor gas memanfaatkan sebuah sumber panas dan menghasilan output berupa panas yang diserap oleh air. Efisiensi pada penelitian ini didefisikan sebagai perbandingan output panas yang diserap oleh air dengan input panas yang dihasilkan oleh bahan bakar, seperti terlihat pada persamaan (1) dibawah ini.

$$
\eta=\frac{m_{a} C_{a} \Delta T}{m_{b b} L H V_{b b}} \times 100 \%
$$

dimana $m_{a}$ adalah massa air, $C_{a}$ adalah panas jenis air dan $\Delta T$ adalah perbedaan awal dan temperatur akhir air, $m_{b b}$ adalah massa bahan bakar, $L H V_{b b}$ adalah nilai kalor bahan bakar.

Definisi efisiensi termal pada persamaan (1) diambil, karena berkaitan dengan energi hilangyang terjadi pada system pemanasan air tersebut. Energi hilang pada sustem pemanasan tersebut relatif komplek untuk didentifiskasi satu persatu karena bentuk geometri dari setiap elemen pemanasan yang cukup komplek. Energi hilang yang relatif mudah untuk diidentifikasi adalah energi hilang yang diakibatkan oleh panas selubung kompor seperti pada persamaan dibawah ini.

$$
\dot{Q}_{\text {rad }}=e \sigma A T^{4}
$$

dimana $A=$ luas penampang, $e$ adalah bahan dan $\sigma$ adalah konstanta Boltzmann yang bernilai $5.67 \times 10^{8} \mathrm{~W} / \mathrm{m}^{2}$. $\mathrm{K}^{4}$

\section{Data Akuisisi}

Untuk memperoleh data-data mengenai temperature, energi radiasi dan massa alir bahan bakar dibuat sebuah instalasi penelitian seperti terlihat pada gambar 1 .

Instalasi penelitian dapat dilihat pada gambar 1. Kompor yang digunakan adalah sebuah kompor gas 1 tungku merk Quantum tipe QGC-101R. Panci yang digunakan adalah sebuah panci standar yang digantung. Skematik gap optimum yang akan dicari pada penelitian ini seperti terlihat pada gambar 2 dibawah ini.

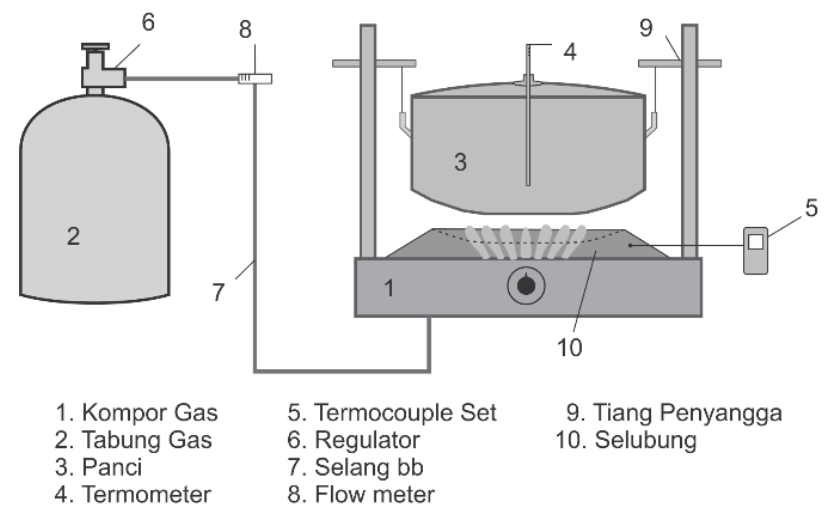

Gambar 1. Ilustrasi instalasi penelitian

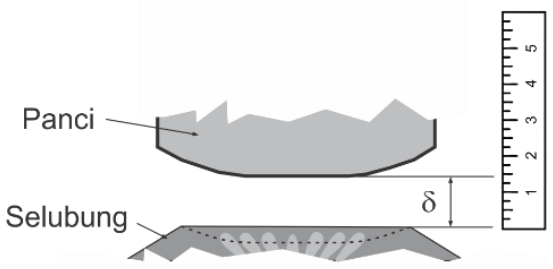

Gambar 2. Skematik gap optimum yang akan diteliti.

Massa alir bahan bakar diukur dengan menggunakan sebuah flow meter merk Omega FL-1501A dengan kapasitas ukur 0.317-3.17 SCFM. Temperatur air diukur dengan menggunakan termometer alkohol tipe AL-30100010 dengan range pengukuran $-10^{\circ} \mathrm{C}-110^{\circ} \mathrm{C}$. Pengukuran permukaan selubung kompor menggunakan termokopel probe tipe $K$ yang dipasang pada thermometer set merk KRISBOW KW06-278 Single Input Digital Thermometer.

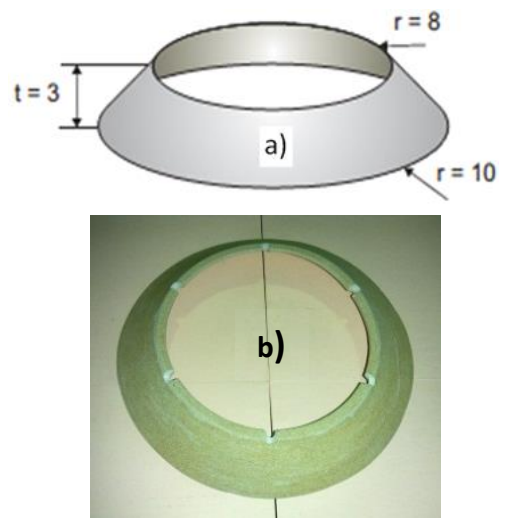

Gambar 3. a) Skematik gambar selubung, b) selubung keramik 
Gambar 3 menunjukkan skematik gambar selubung dan selubung keramik yang digunakan pada penelitian ini. Dimensi selubung yang dipergunakan dalam penelitian ini adalah diameter bawah $10 \mathrm{~cm}$, diameter atas $8 \mathrm{~cm}$, tinggi $3 \mathrm{~cm}$ serta tebal $5 \mathrm{~mm}$. Bentuk selubung adalah kerucut terpotong. Alasan penggunakan bentuk ini karena alasan praktis dalam pemakaian.

\section{Energi Pemasakan}

Energi yang hilang pada proses pemasakan dihitung dengan persamaan dibawah ini (3). Hal ini dilakukan karena kompleksitas dalam pengidentifikasian energi yang hilang akibat mekanisme perpindahan panas konduksi, konveksi dan radiasi dari media selain selubung.

$$
E_{p}=E_{s}+E_{\text {r.sel }}+E_{l}
$$

dimana $E p$ adalah energi yang dihasilkan melalui proses pembakaran, Es adalah energi yang diserap oleh air, Er,sel adalah energi yang dipancarkan oleh selubung dan $E_{l}$ adalah energi yang hilang

Prosedur perhitungan efisiensi dari sistem pemanasan ini dilakukan dengan pendefinisian input dan output energi seperti pada persamaan (1). Efisiensi dihitung persatuan waktu sampai seluruh air mendidih.

\section{Kondisi Penelitian}

Untuk mendapatkan besaran efisiensi pada sistem pemanasan air didapatkan kondisi penelitian seperti terlihat pada tabel 1.

Tabel 1. Kondisi penelitian yang digunakan. Kondisi Penelitian Nilai

$\begin{array}{rll}\text { Massa air } & : & 1 \mathrm{~kg} \\ \text { Temperatur awal air } & : & 25^{\circ} \mathrm{C} \\ \text { Temperatur akhir air } & : & 95^{\circ} \mathrm{C} \\ C_{p} \text { air } & : & 4196 \mathrm{~J} / \mathrm{kg}^{\circ} \mathrm{C} \\ \text { Debit }(Q) \text { gas LPG } & : & 0,0125 \mathrm{~L} / \mathrm{s} \\ \text { Massa jenis ( } \rho \text { ) gas LPG } & : & 0,0021 \mathrm{~kg} / \mathrm{L} \\ \text { LHV gas propana } & : & 46,1 \mathrm{MJ} / \mathrm{kg} \\ \text { LHV gas butana } & : & 46,5 \mathrm{MJ} / \mathrm{kg} \\ \text { Komposisi gas LPG } & : & 30 \% \text { propana } \\ & & 70 \% \text { butana }\end{array}$

Temperatur atmosfer pada saat penelitian adalah $25^{\circ} \mathrm{C}$ dan temperatur akhir sebagai kondisi mendidih adalah $95^{\circ} \mathrm{C}$ akibat dari topografi lokasi penelitian yang berada di ketinggian $\pm 476 \mathrm{~m}$ dpl. Panas jenis air yang digunakan adalah panas jenis air rata-rata pada temperatur operasi. Nilai LHV bahan bakar yang digunakan juga merupakan proporsional komposisi dari bahan bakar LPG sebesar 46365,08 kJ/kg.

\section{HASIL DAN PEMBAHASAN}

Gambar 4 adalah grafik efisiensi per waktu pada berbagai jarak antara selubung dengan panci yang dibandingkan pula dengan efisiensi kompor standar tanpa selubung. Terlihat pada gambar 4 bahwa efisiensi pemanasan mempunyai kecenderungan rendah pada awal pemanasan karena pada awal pemanasan banyak panas yang hasilkan oleh proses pembakaran terserap oleh material sistem pemanasan termasuk selubung dan panci. Akan tetapi pada sekitar 250 detik, efisiensi mulai cenderung konstan dan efisiensinya meningkat melebihi efisiensi kompor standar tanpa selubung (dash line).

Efisiensi tertinggi terjadi pada gap $4 \mathrm{~mm}$ sebesar $46,4 \%$ terpaut $0,1 \%$ dengan gap $5 \mathrm{~mm}$. Efisiensi sebesar ini menghasilkan penghematan waktu pemanasan sebesar 116 detik atau sebanding dengan energi sebesar 141,2 kJ, jika dibandingkan dengan waktu yang dibutuhkan untuk memasak air pada kompor standar tanpa selubung. Efisiensi terbesar pada gap tersebut dikarenakan terjadi kondisi optimum perpindahan panas konveksi dan radiasi yang terjadi pada sistem pemanasan ini.

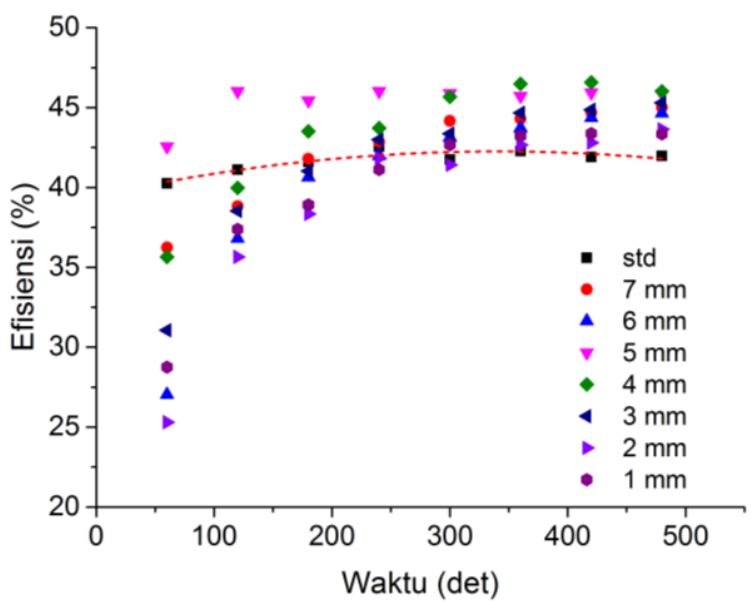

Gambar 4. Efisiensi kompor per satuan waktu untuk berbagai gap

Garis polinomial dilakukan pada efisiensi dan energi yang hilang, $E_{l}$, pada berbagai variasi gap selubung dan panci dapat dilihat pada gambar 5 . Efisiensi tertinggi terjadi pada gap 4 dan $5 \mathrm{~mm}$ dan selainnya menunjukkan efisiensi yang 
cenderung menurun. Hal ini ditunjukkan oleh

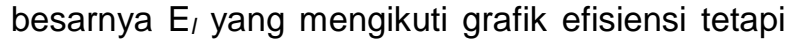
dalam kondisi yang berkebalikan.

Ketika efisiensi mencapai titik tertinggi, maka grafik $E_{/}$akan menunjukkan titik terendah. $E_{\text {/ }}$ sebesar 0,34 MJ merupakan $E_{l}$ terkecil.

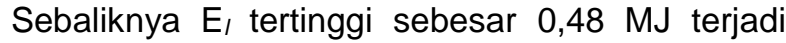
pada pemansan dengan menggunakan kompor standar.

Garis polinomial juga diplot untuk energi pembakaran $E p$ dan energi radiasi selubung Er,sel seperti terlihat pada gambar 6. Norm. Er,sel merupakan normalisasi energi radiasi selubung dengan energi hilang $E_{l}$ pada berbagai variaasi gap. Pada gambar 6 terlihat bahwa gap $1 \mathrm{~mm}$ mengindikasikan Norm. Er,sel tertinggi sebesar $4,31 \times 10^{-3}$. Hal ini menunjukan bahwa meskipun energi radiasi paling besar (ditandai dengan temperatur permukaan selubung paling tinggi sebesar $323,3^{\circ} \mathrm{C}$ ) akan tetapi energi yang hilang pada gap $1 \mathrm{~mm}$ (dari proses perpindahan panas konveksi) relatif tidak begitu besar jika dibandingkan dengan gap yang lain. Pada gap $6 \mathrm{~mm}$, Norm Er,sel menunjukan nilai terendah sebesar $3,17 \times 10^{-3}$ meskipun gap $6 \mathrm{~mm}$ bukan merupakan gap yang mempunyai efisiensi terendah. Hal ini menunjukan bahwa meskipun Er,sel pada gap 6 $\mathrm{mm}$ bukan merupakan yang terkecil, akan tetapi energi akibat perpindahan konveksi hampir mencapai energi yang hilang terbesar pada penelitian ini.

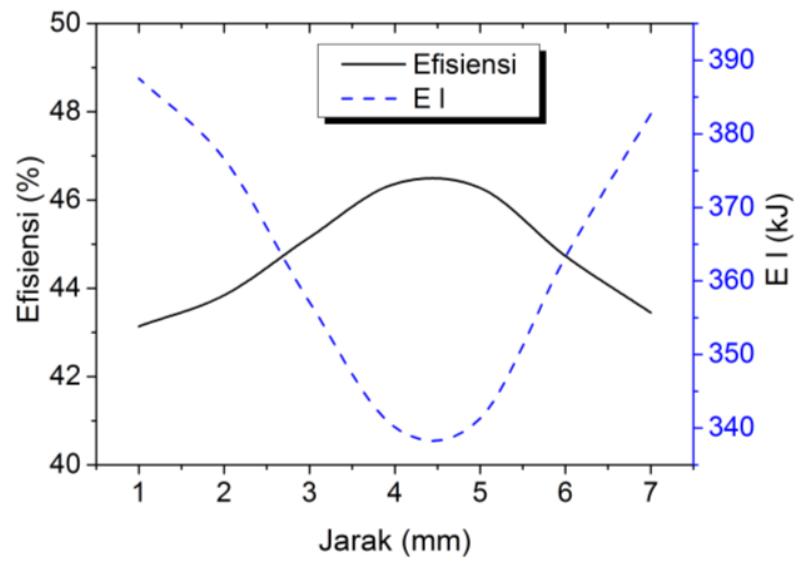

Gambar 5. Garis polinomial efisiensi dan energi yang hilang selama proses pemanasan.

Garis polinomial energi yang dihasilkan pada proses pembakaran, $E p$ (dash line pada gambar 6) menunjukkan kecenderungan yang energi hilang, $E l$, yaitu berbanding terbalik dengan efisiensi. Nilai tertinggi diperoleh pada gap $1 \mathrm{~mm}$ yang artinya pada gap ini dibutuhkan energi yang besar untuk proses pemanasan. Sebaliknya energi pembakaran terkecil diperoleh pada gap $4 \mathrm{~mm}$.

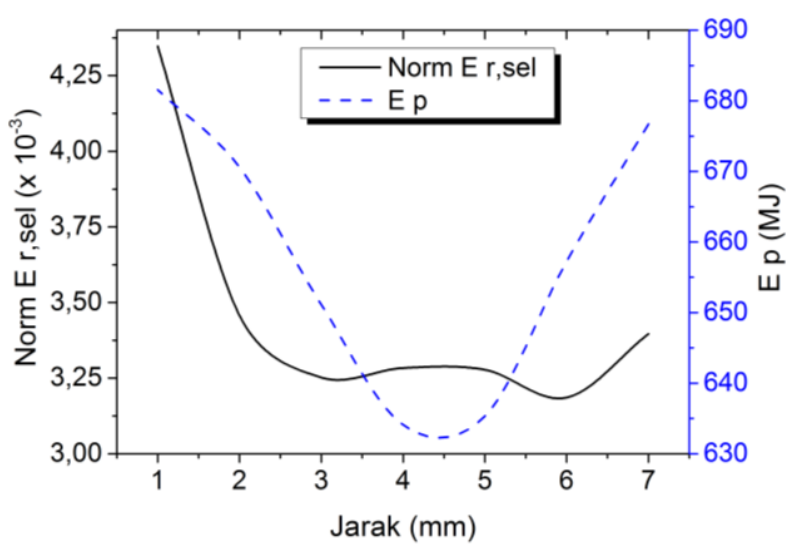

Gambar 6. Norm E r,sel dan energi pembakaran pada sistem pemanasan air.

\section{KESIMPULAN DAN SARAN}

Diskusi pada hasil dan pembahasan menunjukkan beberapa kesimpulan yang dapat diambil. Selain penggunaan selubung yang dapat meningkatkan efisiensi sistem pemanasan air, dapat pula diambil kesimpulan sebagai berikut :

Jarak antara selubung dengan panci mempengaruhi efisiensi sistem pemanasan. Pada sebuah massa alir bahan bakar yang konstan sebesar 0,0125 L/s pada kompor standar efisiensi terbesar diperoleh pada gap $4 \mathrm{~mm}$.

- Efisiensi paling tinggi yang diperoleh adalah $46,36 \%$ yang menunjukkan bahwa terjadi kondisi optimum antara perpindahan panas radiasi dan konveksi.

\section{UCAPAN TERIMA KASIH}

Penulis mengucapkan banyak terima kasih kepada Fakultas Teknik Universitas Brawijaya atas biaya DIPA yang diberikan dengan nomor kontrak No./UN.10.6/PG/2014 sehingga penelitian ini dapat terselesaikan. Ucapkan terima kasih pula penulis sampaikan kepada saudara Mohammad Hasan Ashari atas bantuan dalam pelaksanaan penelitian ini serta semua pihak yang tidak dapat penulis sebutkan satu persatu.

\section{DAFTAR PUSTAKA}

[1] Konversi BBM ke Gas, Kurangi Subsidi BBM Jangka Panjang,

http://www.esdm.go.id/berita/40-migas/5515konversi-bbm-ke-gas-kurangi-subsidi-bbmjangka-panjang.html.

[2] Panduan Masyarakat Tentang Subsidi Energi Di Indonesia Perkembangan Terakhir 2012, http://www.iisd.org/gsi/sites/default/files/indon 
esia_czguide_bahasa_update_2012.pdf, hal. 11

[3] Konversi Mitan Ke LPG Hemat Rp 70 Triliun", 2014. http://www.esdm.go.id/berita/migas/40migas/ 6513-konversi-mitan-ke-lpg-hemat-rp70-triliun.html).

[4] Gohil , P.P and Channiwala, S.A., 2011., "Fundamental J. Thermal Science and Engineering", Vol. 1, Issue 1, 2011, Pages 25-34

[5] Khan, M.Y and Saxena A.," Performance of LPG Cooking Stove Using Different Design Of Burner Heads", International Journal of Engineering Research \& Technology (IJERT), ISSN: 2278-0181, Vol. 2 Issue 7, July -2013.
[6] Syarial, M., 2012, “Unjuk Kerja Kompor Berbahan Bakar Biogas Efisiensi Tinggi Dengan Penambahan Reflektor"., Skripsi Unpublihed 2012. Institut Teknologi Sepuluh November. Surabaya.

[7] Wardani, D. 2007. "Alat Penghemat Bahan Bakar Gas Pada Kompor Gas Rumah Tangga". Skripsi Unpublished. Institut Teknologi Bandung.

[8] Widiandra, P. 2014, Pengaruh Material Selubung Sebagai Isolator Terhadap Efisiensi Sistem Pemanasan Menggunakan Kompor Gas, Skripsi Teknik Mesin Fakultas Teknik Universitas Brawijaya, Malang.

[9] Widodo, A.S., Selubung Radiasi Untuk Efisiensi Penggunaan Energi Pada Kompor Gas, Jurnal Rekayasa Mesin Vol.5, No.3 Tahun 2014: 291-295 